\title{
PEMANFAATAN BELUT (Monopterus albus) PADA PEMBUATAN CENDOL KAYA PROTEIN
}

\section{Utilization of eel (Monopterus albus) in the making of protein-rich cendol}

\author{
Novia Anggraenia*, Luqmanul Hakim ${ }^{\mathrm{b}}$, dan Fath Fadhilah W. ${ }^{\mathrm{b}}$ \\ aprogram Studi Teknologi Pangan, Fakultas Sains dan Teknologi, Universitas Nasional Karangturi, Semarang, Indonesia \\ bProgram Studi Teknologi Hasil Perikanan, Fakultas Perikanan dan Ilmu Kelautan, Universitas Diponegoro, Semarang, Indonesia \\ Doi: 10.37195/jac.v2i2.118
}

*KORESPONDENSI

Telepon: +62-857-4388-5344

E-mail: novia.anggraeni@unkartur.ac.id

\section{JEJAK PENGIRIMAN}

Diterima: 19 Sep 2020

Revisi Akhir: 28 Sep 2020

Disetujui: 29 Sep 2020

\section{KEYWORDS}

Cendol, Eel (Monopterus albus), Diversification

\section{KATA KUNCI}

Cendol, Belut (Monopterus albus), Diversifikasi

\begin{abstract}
Cendol is a typical Indonesian drink that has a chewy texture but has incomplete nutritional content. One alternative to supplement the nutritional content of cendol products is to diversify food. The addition of eels to cendol products is one of the processes of food diversification which also aims to increase the selling value of eels in the local Indonesian market. This study aims to evaluate the use of eel on the characteristics and nutritional value of cendol products. This study used an experimental experiment with 4 treatments of adding eels of 0\%, 10\%, 20\%, and $30 \%$. The selected cendol from the organoleptic test was cendol with the addition of $10 \%$ eel with $71.06 \%$ water content, $1.22 \%$ fat content, $4 \%$ protein content, $23.37 \%$ carbohydrate, and $0.45 \%$ ash content.
\end{abstract}

Cendol merupakan minuman khas Indonesia yang memiliki tekstur yang kenyal namun memiliki kandungan gizi yang belum lengkap. Salah satu alternative untuk melengkapi kandungan gizi dari produk cendol adalah dengan melakukan diversifikasi pangan. Penambahan belut pada produk cendol merupakan salah satu proses dari diversifikasi pangan yang bertujuan juga untuk meningkatkan nilai jual belut di pasar lokal Indonesia. Penelitian ini bertujuan untuk mengevaluasi pemanfaatan daging belut terhadap karakteristik dan nilai gizi produk cendol. Penelitian ini menggunakan percobaan eksperimental dengan 4 perlakuan penambahan belut sebesar $0 \%$, $10 \%$, 20\%, dan $30 \%$. Cendol terpilih dari pengujian organoleptik adalah cendol dengan penambahan belut $10 \%$ dengan kadar air $71,06 \%$, kadar lemak 1,22\%, kadar protein $4 \%$, karbohidrat 23,37\%, dan kadar abu $0,45 \%$.

\section{PENDAHULUAN}

Rendahnya tingkat konsumsi protein masyarakat Indonesia merupakan salah satu permasalahan ketahanan pangan. Hal ini ditunjukkan dengan belum terpenuhinya standar AKG yang sudah dianjurkan oleh pemerintah. Padahal di Indonesia sendiri terdapat banyak jenis sumber protein yang mudah didapatkan, seperti contohnya ikan yang merupakan salah satu sumber protein hewani. Menurut Kementrian Kelautan dan Perikanan, tingkat konsumsi ikan pada tahun 2019 belum bisa mengalahkan negara Malaysia, Singapura, dan Jepang yang sudah mencapai lebih dari 60 $\mathrm{kg} / \mathrm{kapita} /$ tahun. Disisi lain, Indonesia merupakan negara maritim dengan potensi perikanan tangkap maupun perikanan budidaya yang lebih besar dibandingkan negara-negara tetangga. Menurut Nugroho, Sukadi, \& Huwoyon (2012), hasil perikanan budidaya berpotensi besar bagi pelaku ekspor. Beberapa ikan budidaya asli Indonesia pun sudah mulai dikenal di dunia internasional sehingga berpotensi untuk terus dikembangkan. Belut 
adalah salah satu komoditas perikanan budidaya yang cukup popular ditengah masyarakat. Selain itu, belut (Monopterus albus) adalah komoditas ekspor dengan permintaan yang cukup tinggi. Permintaan belut di beberapa negara Asia berkisar 60 ton per hari, sedangkan untuk permintaan olahan belut dibeberapa negara asia berkisar 3 ton, belum lagi negara Uni Eropa yang memiliki permintaan 1 ton per hari. Sedangkan untuk produksi budidaya belut di Indonesia pada tahun 2017 mencapai tahun 2017 mencapai 7.731 ton. Permintaan komoditas belut pada ekspor berbanding terbalik dengan permintaan pasar lokal di Indonesia.

Belut di Indonesia kurang digemari oleh masyarakat karena bentuknya yang menyerupai ular sehingga perlu dilakukan diversifikasi produk untuk menaikkan minat masyarakat terhadap komuditas belut segar. Diversifikasi produk merupakan salah satu upaya yang dapat dilakukan untuk menciptakan produk baru dari bahan baku yang kurang digemari oleh masyarakat. Menurut Frison dan Clément (2020) menyatakan bahwa, membuat produk baru dengan bahan baku yang bernilai ekonomi rendah akan menjadi salah satu cara untuk mengatasi beberapa permasalahan ketahanan pangan. Di sisi lain, kandungan protein pada belut cukup tinggi sehingga dapat memenuhi AKG masyarakat Indonesia yaitu 57 gram per hari. Penelitian Candra dan Rahmawati (2018) menyatakan bahwa kandungan protein dari belut segar cukup tinggi yaitu 18,49 gram.100 ${ }^{-1}$ gram, lebih tinggi dibandingkan protein telur.

Produk diversifikasi dari belut segar yang sudah ada di Indonesia masih sangat sedikit. Beberapa produk yang sudah popular adalah keripik belut, abon belut, dan sambal belut. Sehingga komoditas belut masih perlu dikembangkan agar dapat menghasilkan produk baru yang dapat diterima di masyarakat. Diversifikasi produk pada penelitian ini adalah mengolah daging belut yang biasanya hanya dijual secara segar menjadi produk minuman khas yang sangat popular yaitu cendol. Dengan berbagai macam potensi dan nilai gizi dari belut, maka dapat dilakukan penelitian yang bertujuan untuk mengetahui pengaruh pemanfaatan daging belut terhadap karakteristik dan nilai gizi produk cendol.

\section{BAHAN DAN METODE}

\section{Bahan}

Bahan yang digunakan dalam penelitian ini diantaranya adalah belut segar yang didapatkan dari pembudidaya Desa Kandri, Kota Semarang. Sedangkan untuk bahan pendukung lainnya seperti tepung tapioka, daun suji,dan santan diperoleh dari pasar tradisional di Kota Semarang.

\section{Desain Penelitian}

Penelitian ini merupakan penelitian eksperimental dengan Rancangan Acak Lengkap yang terdiri dari tiga tahap penelitian yaitu pembuatan cendol dengan variasi konsentrasi belut, penliaian organoleptik, dan pengujian proksimat. Formulasi cendol dengan penambahan daging belut tersaji pada Tabel 1 . Penentuan formula cendol yang paling disukai atau cendol terpilih oleh 30 panelis terlatih dengan melakukan pengamatan terhadap parameter kenampakan, warna, tekstur, aroma dan rasa. Skor penilaian berdasarkan skala numerik 9-1 dengan skala hedonik amat sangat suka-amat sangat tidak suka. Cendol dengan formulasi terpilih selanjutnya dilakukan pengujian kadar air, kadar lemak, kadar abu, kadar protein, dan karbohidrat.

Tabel 1. Formulasi cendol belut

\begin{tabular}{ccccc}
\hline No. & $\begin{array}{c}\text { Daun } \\
\text { suji } \\
(\mathrm{ml})\end{array}$ & $\begin{array}{c}\text { Santan } \\
(\mathrm{ml})\end{array}$ & $\begin{array}{c}\text { Tepung } \\
\text { tapioka } \\
(\mathrm{g})\end{array}$ & $\begin{array}{c}\text { Belut } \\
(\%)\end{array}$ \\
\hline 1 & 10 & 100 & 80 & 0 \\
\hline 2 & 10 & 100 & 80 & 10 \\
\hline 3 & 10 & 100 & 80 & 20 \\
\hline 4 & 10 & 100 & 80 & 30 \\
\hline
\end{tabular}

\section{HASIL DAN PEMBAHASAN}

\section{Penampakan}

Hasil uji organoleptik parameter berkisar antara 7,16 sampai 7,6 yang tersaji pada (Gbr. 1). Cendol terbaik pada parameter penampakanyaitu cendol dengan perlakuan penambahan belut sebesar 10\%. Pengujian organoleptik pada parameter penampakan merupakan salah satu parameter utama yang akan dinilai oleh panelis sebelum parameter yang lainnya. Penambahan belut pada pembuatan cendol berpengaruh nyata 
terhadap penampakan cendol. Semakin banyak konsentrasi belut yang ditambahkan, maka akan semakin rendah penilaian panelis terhadap parameter penampakan. Hal ini dikarenakan tekstur belut yang kenyal akan menciptakan penampakan cendol yang lebih padat dan menarik. Penelitian El-Obeid et al. (2018), berupa produk olahan belut menjadi produk fillet memiliki penilaian yang dapat diterima oleh panelis karena memiliki penampakan yang padat dan utuh.

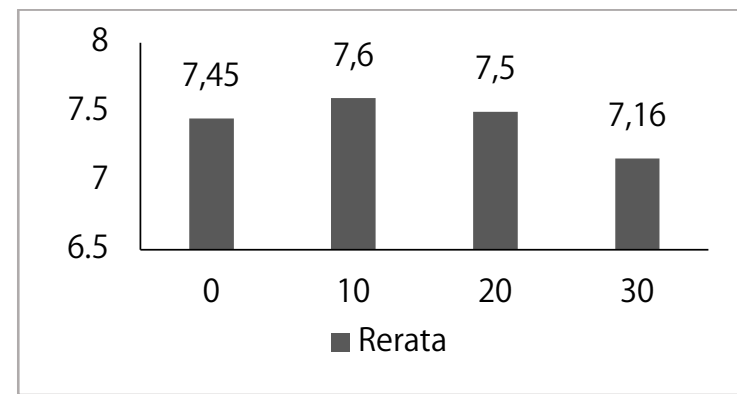

Gbr. 1. Hasil organoleptik parameter penampakan

\section{Rasa}

Hasil Organoleptik parameter rasa yang tersaji pada Gbr. 2 menunjukkan bahwa penambahan belut memberikan pengaruh nyata. Hasil organoleptik parameter rasa berkisar antara 7,41 sampai 7,80. Cendol terbaik ada pada perlakuan penambahan belut 10\%. Hal ini disebabkan oleh rasa umami yang dihasilkan oleh belut itu sendiri. Seperti yang diketahui, rasa umami merupakan citarasa yang enak dan gurih. Cita rasa ini sangat popular di masyarakat Jepang, dan masih bisa diterima oleh panelis di Indonesia. Wang, Zhou, dan Liu (2020) menyatakan bahwa, cita rasa umami biasa dikenal dengan cita rasa gurih yang dapat meningkatkan cita rasa berbagai makanan. Umami juga berperan dalam metabolisme tubuh sehingga dapat meningkatkan nafsu makan.

\section{Warna}

Hasil uji organoleptik, parameter warna menghasilkan nilai berkisar 6,13 sampai 6,5 dengan warna yang paling disukai panelis yaitu perlakuan penambahan belut $10 \%$. Berdasarkan pengujian ini, penambahan belut berpengaruh nyata terhadap rasa dari produk cendol. Hal ini disebabkan oleh semakin tinggi konsentrasi belut yang ditambahkan maka akan meningkatkan kepekatan warna dari produk cendol. Pada Gbr. 3 terlihat bahwa semakin pekat warna yang dihasilkan maka penliaian panelis terhadap parameter warna akan semakin rendah. Namun masih dalam kategori nilai 6 yang berarti agak suka. Hal ini disebabkan karena adanya penambahan warna alami dari daun suji yang memiliki klorofil. Wen et al. (2019) menyatakan bahwa, pewarna alami yang dihasilkan oleh klorofil akan menghasilkan warna menarik apabila ditambahkan pada suatu produk.

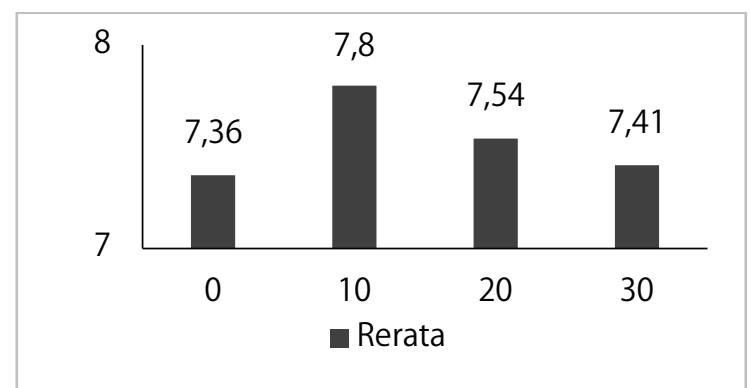

Gbr. 2. Hasil organoleptik parameter rasa

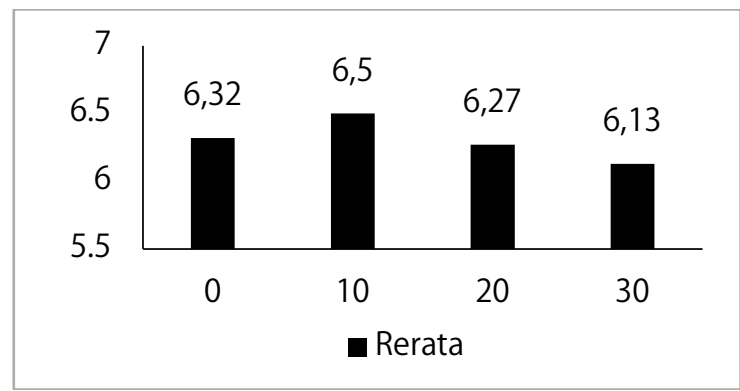

Gbr. 3. Hasil organoleptik parameter warna

\section{Aroma}

Hasil uji organoleptik parameter aroma menghasilkan nilai berkisar 6,25 sampai 6,63 yang tersaji pada Gbr. 4. Berdasarkan uji chi-square menunjukkan bahwa pemanfaatan belut sebagai bahan baku pembuatan cendol memberikan pengaruh nyata terhadap aroma dari produk cendol. Namun, cendol kontrol atau tanpa penambahan belut memiliki nilai tertinggi yaitu 6,63. Hal ini disebabkan oleh aroma amis yang masih tersisa pada produk cendol belut. Sehingga diperlukan penelitian lanjutan untukmenghilangkan aroma amis yang dihasilkan oleh bahan baku pembuatan cendol yaitu belut. Hasil penelitian Li et al. (2019) menunjukkan bahwa bau atau aroma amis yang dihasilkan oleh beberapa sumber protein hewani akan menurunkan tingkat kesukaan panelis. 


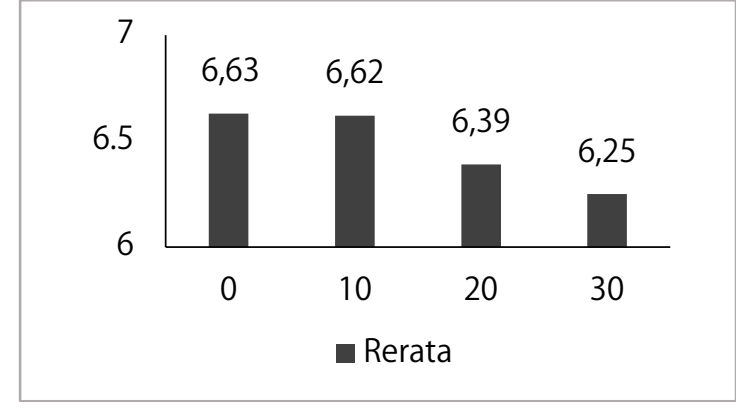

Gbr. 4. Hasil organoleptik parameter aroma

\section{Tekstur}

Hasil uji organoleptik parameter tekstur yang disajikan pada Gbr. 5 menunjukkan bahwa penambahan belut memberikan pengaruh beda nyata terhadap cendol kontrol atau tanpa penambahan belut. Ketiga perlakuan penambahan belut pada cendol memiliki nilai tekstur yang cukup tinggi yaitu 7,4. Tekstur cendol belut dapat diterima oleh panelis dikarenakan adanya komponen santan yang akan menciptakan tekstur produk yang lembut. Selain itu juga dipengaruhi oleh tekstur kenyal dari belut segar yang akan menghasilkan produk olahan dengan tekstur yang kenyal pula. Damusaru et al. (2019) menyatakan bahwa, pada dasarnya daging belut segar memiliki tekstur yang kenyal sehingga cocok digunakan untuk berbagai macam produk olahan.

\section{Analisa Proksimat}

Hasil analisis proksimat dilakukan pada prduk cendol kontrol tanpa penambahan belut dan cendol terpilih yaitu dengan perlakuan penambahan belut $10 \%$ yang tersaji pada Tabel 2. Hasil pengujian kadar air pada produk cendol kontrol dan cendol terpilih masing masing 91,09\% dan 71,06\%. Kadar air yang disajikan pada Tabel 2 menunjukkan bahwa cendol kontrol memiliki kadar air yang lebih tinggi jika dibandingkan dengan cendol dengan penambahan belut 10\%. Adanya perbedaan hasil kadar air yang dihasilkan dipengaruhi oleh komposisi bahan penyusun pada produk cendol. Komposisi yang lebih beragam terdapat pada cendol terpilih sehingga kemampuan menyerap air lebih besar dibandingkan dengan cendol kontrol.

Faktor utama yang akan mempengaruhi masa simpan dari suatu produk adalah kandungan kadar air, sehingga beberapa produk dengan masa simpan yang singkat akan memiliki nilai kadar air yang tinggi, begitu juga sebaliknya. Kamau et al. (2018) menjelaskan bahwa, untuk menentukan daya tahan atau masa simpan dari suatu produk, biasanya akan dilihat terlebih dahulu kandungan kadar air yang dimiliki oleh produk tersebut.

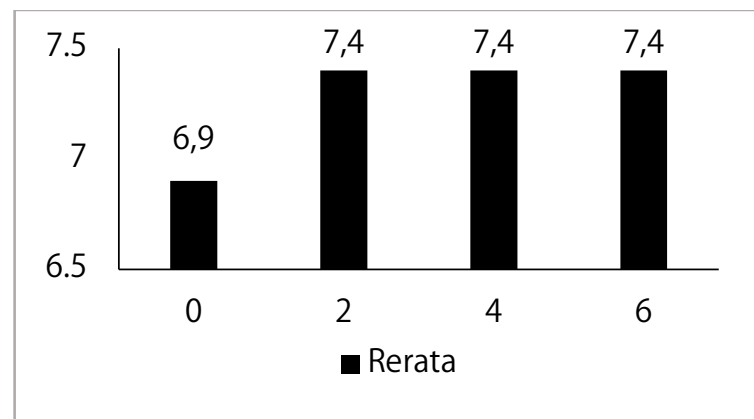

Gbr. 5. Hasil organoleptik parameter tekstur

Tabel 2. Proksimat cendol

\begin{tabular}{|c|c|c|c|}
\hline No. & Parameter & $\begin{array}{l}\text { Cendol } \\
\text { Kontrol }\end{array}$ & $\begin{array}{c}\text { Cendol Kopi } \\
4 \mathrm{~g}\end{array}$ \\
\hline 1 & Kadar air (\%) & $91,09 \pm 0,18^{*}$ & $71,06 \pm 0,15^{*}$ \\
\hline 2 & Kadar lemak (\%) & $0,27 \pm 0,04^{*}$ & $1,22 \pm 0,01 *$ \\
\hline 3 & Kadar protein (\%) & $01,15 \pm 0,17^{*}$ & $4 \pm 0,04^{*}$ \\
\hline 4 & $\begin{array}{l}\text { Kadar } \\
\text { karbohidrat (\%) }\end{array}$ & $7,39 \pm 0,37^{*}$ & $23,27 \pm 0,87^{*}$ \\
\hline 5 & Kadar abu (\%) & $0,10 \pm 0,11^{*}$ & $0,45 \pm 0,17^{*}$ \\
\hline
\end{tabular}

Hasil pengujian kadar lemak menunjukkan bahwa cendol dengan penambahan belut $10 \%$ menghasilkan lemak yang lebih tinggi dari cendol kontrol. Kadar lemak dari cendol terpilih sebesar $1,22 \%$ sedangkan cendol kontrol sebesar $0,27 \%$. Tingginya kadar lemak pada cendol terpilih disebabkan oleh bahan baku yang digunakan. Belut memiliki kandungan lemak yang cukup tinggi sehingga akan menghasilkan produk olahan dengan kadar lemak yang tinggi pula. Hasil penelitian Farris et al. (2020) menunjukkan bahwa, selain memiliki kandungan protein dan omega 3 yang tinggi, belut segar juga memiliki kandungan lemak yang cukup tinggi yaitu sebesar 6,37\%.

Hasil pengujian kadar protein yang disajikan pada Tabel 2 menunjukkan bahwa cendol dengan penambahan belut $10 \%$ memiliki kadar protein yang lebih tinggi dibandingkan cendol kontrol. Cendol terpilih memiliki kadar protein $4 \%$ sedangkan cendol kontrol memiliki kadar protein sebesar $1,15 \%$. Kadar protein ini dipengaruhi oleh penggunaan belut pada pembuatan cendol. Hasil penelitian Budiarti, Swastawati, dan Rianingsih (2016) 
menunjukkan bahwa, daging belut segar memiliki kadar protein sebesar 44,52\%.

Selain itu, tingginya kadar protein pada cendol terpilih juga dipengaruhi oleh tingginya jumlah protein pada bahan baku seperti tepung tapioka dan santan. Semakin tinggi jumlah protein pada bahan baku seperti daging ikan, tepung tapioka, santan, kadar protein juga sama pentingnya dengan kadar air dalam menentukan masa simpan dari suatu produk. Hasil penelitian Walayat et al. (2020) menunjukkan bahwa kadar protein merupakan faktor utama yang diperhatikan pada pengujian TVBN sebagai satu pengujian untuk menentukan masa simpan produk. Hasil pengujian kadar karbohidrat yang disajikan pada Tabel 2 menunjukkan bahwa produk cendol dengan penambahan belut $10 \%$ memiliki kadar karbohidrat yang tinggi yaitu 23,27\%, sedangkan untuk cendol kontrol memiliki karbohidrat 7,39\%. Hal ini disebabkan karena daging belut memiliki karbohidrat yang cukup tinggi. Hasil dari Analisa karbohidrat ini akan berbanding terbalik dengan kadar air. Semakin rendah nilai karbohidrat pada suatu produk maka akan kadar air yang dihasilkan akan semakin tinggi dan mempengaruhi sifat higroskopis bahan tersebut.

Hasil pengujian kadar abu yang disajikan pada Tabel 2 menunjukkan bahwa cendol dengan penambahan belut $10 \%$ memiliki kadar abu yang lebih tinggi yaitu $0,45 \%$, sedangkan pada cendol kontrol sebesar 0,10\%. Hasil penelitian Andini, Virginia, dan Hartini (2015) menunjukkan bahwa tempe yang diberi perlakuan dengan menambahkan daging belut, menghasilkan kadar abu sebesar 1,63\%.

Nilai kadar abu berbanding lurus dengan nilai kadar protein, semakin tinggi kadar protein maka akan semakin tinggi pula nilai dari kadar abu, dan begitu pula sebaliknya. Tingginya kadar abu pada produk cendol terpilih ini disebabkan oleh tingginya mineral yang terkandung pada belut. Menurut Anggraeni, Darmanto, dan Riyadi (2016) yang menyatakan bahwa semaakin tinggi kadar abu suatu bahan pangan maka akan mengindikasikan semakin tinggi pula mineral yang terkandung pada bahan pangan tersebut.

\section{KESIMPULAN}

Pemanfaatan belut sebagai bahan baku pembuatan cendol berpengaruh nyata terhadap pengujian organoleptik disemua parameter. Cendol terpilih adalah cendol perlakuan penambahan belut $10 \%$ dengan kadar air $71,06 \%$, kadar lemak 1,22\%, kadar protein $4 \%$, karbohidrat 23,37\%, dan kadar abu 0,45\%.

\section{DAFTAR PUSTAKA}

Andini, S., Virginia, G., \& Hartini, S. (2015). Peningkatan kadar protein, lemak, dan asam lemak tak jenuh pada tempe akibat penambahan tepung belut (Monopterus albus zuieuw) dan uji sensoris tempe belut. Jurnal Teknologi Pangan dan Hasil Pertanian, 12(1), 32-43. http://journals.usm.ac.id/index.php/ jtphp/article/view/480/287

Anggraeni, N., Darmanto, Y. S., \& Riyadi, P. H. (2016). Pemanfaatan nanokalsium tulang ikan nila (Oreochromis niloticus) pada beras analog dari berbagai macam ubi jalar (Ipomoea batatas L.). Jurnal Aplikasi Teknologi Pangan, 5(4), 114-122. https://doi.org/10.17728/jatp.187

Candra, C., \& Rahmawati, H. (2018). Peningkatan Kandungan Protein Mie Basah Dengan Penambahan Daging Ikan Belut (Monopterus albus Zuieuw). Jukung (Jurnal Teknik Lingkungan), 4(1), 82-86. https://doi.org/10.20527/jukung.v4i1.4665

Damusaru, J. H., Moniruzzaman, M., Park, Y., Seong, M., Jung, J. Y., Kim, D. J., \& Bai, S. C. (2019). Evaluation of fish meal analogue as partial fish meal replacement in the diet of growing Japanese eel Anguilla japonica. Animal Feed Science and Technology, 247, 41-52. https://doi.org/10.1016/j.anifeedsci. 2018.10.018

Budiarti, I. D. S., Swastawati, F., \& Rianingsih, L. (2016). Pengaruh perbedaan lama perendaman dalam asap cair terhadap perubahan komposisi asam lemak dan kolesterol belut (Monopterus albus) asap. Jurnal Pengolahan dan Bioteknologi Hasil Perikanan, 5(1), 125-135.

El-Obeid, T., Yehia, H. M., Sakkas, H., Lambrianidi, L., Tsiraki, M. I., \& Savvaidis, I. 
N. (2018). Shelf-life of smoked eel fillets treated with chitosan or thyme oil. International Journal of Biological Macromolecules, 114, 578-583. https://doi. org/10.1016/j.ijbiomac.2018.03.125

Farris, N. W., Kim, D., Hamidoghli, A., Won, S., Lee, S., Bae, J., \& Bai, S. C. (2020). Dietary $\alpha-$ Tocopheryl acetate and arachidonic acid synergistically improves superoxide dismutase activity in female Japanese eel broodstock, Anguilla japonica. Aquaculture, 522, 735100. https://doi.org/10.1016/ j.aquaculture.2020.735100

Frison, E., \& Clément, C. (2020). The potential of diversified agroecological systems to deliver healthy outcomes: Making the link between agriculture, food systems \& health. Food Policy, 96, 101851. https://doi.org/ 10.1016/j.foodpol.2020.101851

Kamau, E., Mutungi, C., Kinyuru, J., Imathiu, S., Tanga, C., Affognon, H., ... Fiaboe, K. K. M. (2018). Moisture adsorption properties and shelf-life estimation of dried and pulverised edible house cricket Acheta domesticus (L.) and black soldier fly larvae Hermetia illucens (L.). Food Research International, 106, 420427.

https://doi.org/10.1016/j.foodres.2018.01.0 12

Li, X., Huang, M., Song, J., Shi, X., Chen, X., Yang, F., ... Zheng, J. (2019). Analysis of fishy taint in duck eggs reveals the causative constituent of the fishy odor and factors affecting the perception ability of this odor. Poultry Science, 98(10), 5198-5207. https://doi.org/10.3382/ps/pez260

Nugroho, E., Sukadi, M. F., \& Huwoyon, G. H. (2012). Beberapa jenis ikan lokal yang potensial untuk budidaya: Domestikasi, Teknologi Pembenihan, dan Pengelolaan Kesehatan Lingkungan Budidaya. Media Akuakultur, 7(1), 52-57. https://doi.org/ 10.15578/ma.7.1.2012.52-57

Walayat, N., Xiong, Z., Xiong, H., Moreno, H. M., Niaz, N., Ahmad, M. ... Wang, P. K. (2020). Cryoprotective effect of egg white proteins and xylooligosaccharides mixture on oxidative and structural changes in myofibrillar proteins of Culter alburnus during frozen storage. International Journal of Biological Macromolecules, 158, 865-874. https://doi.org/10.1016/j.ijbiomac.2020.04. 093
Wang, W., Zhou, X., \& Liu, Y. (2020). Characterization and evaluation of umami taste: A review. TrAC - Trends in Analytical Chemistry, 127, 115876. https://doi.org/ 10.1016/j.trac.2020.11586

Wen, B., Li, C., Fu, X., Li, D., Li, L., Chen, X., ... Gao, D. (2019). Effects of nitrate deficiency on nitrate assimilation and chlorophyll synthesis of detached apple leaves. Plant Physiology and Biochemistry, 142, 363-371. https://doi.org/10.1016/j.plaphy. 2019.07.007 